\title{
DÜBLIN
}

Technological University Dublin ARROW@TU Dublin

2011-04-01

\section{Irish Corned Beef: A Culinary History}

Máirtín Mac Con lomaire

Technological University Dublin, mairtin.macconiomaire@tudublin.ie

Pádraic Óg Gallagher

Gallagher's Boxty House, Pog@boxtyhouse.ie

Follow this and additional works at: https://arrow.tudublin.ie/tfschafart

Part of the Cultural History Commons, Food Studies Commons, and the Social History Commons

\section{Recommended Citation}

Mac Con Iomaire, M. and P. Gallagher (2011) Irish Corned Beef: A Culinary History. Journal of Culinary Science and Technology. Vol 9, No. 1, DOI: 10.21427/d7b179

This Article is brought to you for free and open access by the School of Culinary Arts and Food Technology at ARROW@TU Dublin. It has been accepted for inclusion in Articles by an authorized administrator of ARROW@TU Dublin. For more information, please contact arrow.admin@tudublin.ie, aisling.coyne@tudublin.ie, gerard.connolly@tudublin.ie.

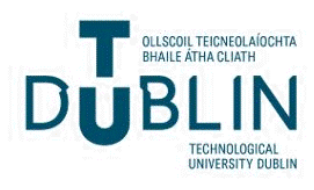




\title{
Irish Corned Beef: A Culinary History
}

\begin{abstract}
This article proposes that a better knowledge of culinary history enriches all culinary stakeholders. The article will discuss the origins and history of corned beef in Irish cuisine and culture. It outlines how cattle have been central to the ancient Irish way of life for centuries, but were cherished more for their milk than their meat. In the early modern period, with the decline in the power of the Gaelic lords, cattle became and economic commodity that was exported to England. The Cattle Acts of 1663 and 1667 affected the export trade of live cattle and led to a growing trade in salted Irish beef, centred principally on the city of Cork. Irish corned beef provisioned the British navy fleets for over two centuries. It was also shipped to the English and French colonies. The paper discusses the growth of the corned beef industry and how Irish immigrants popularised corned beef and cabbage in America. It also presents evidence of corned beef consumption in Ireland as a festive food. Changing meat consumption patterns in modern Ireland are discussed and the negative influence of canned South American 'bully beef' on traditional Irish corned beef is highlighted. The influence of war on changing dietary habits and on accelerating food innovation is also discussed.
\end{abstract}

KEYWORDS: Corned Beef, Ireland, Irish Cuisine, Keg, Salt Beef, Slave Food, Culinary History, Immigration

\section{INTRODUCTION}

There has been a growing interest in culinary history and gastronomy in the last three decades (Messer et al., 2000). Culinary history research at doctoral level has been gradually increasing (Barlösius, 1988; Spang, 1993; Trubek, 1995; Mac Con Iomaire, 2009; O'Gorman, 2010). In the inaugural editorial of the new Journal of Culinary Science and Technology (Vol. 4, No. 1, 2005), culinary history was among the many different disciplines from which the editors suggested that they would draw in-depth articles. The study of a particular commodity or ingredient can uncover how it has influenced and been influenced by scientific, political, sociological and commercial developments over time. Examples of such studies include Mintz (1986) on Sugar, Coe (2003) on Chocolate, Montgomery (2003) on Salmon, Turner (2005) on Spices, Albala (2007) on Beans, Reader (2008) on Potatoes, and Kurlansky on Cod (1997), Salt (2002) and the Oyster (2007). McGee (1992, 2004) has combined the science, lore, history and culture of food in his seminal works on culinary science. It is proposed that a better understanding of culinary history enriches all culinary 
stakeholders including consumers, food technologists, research chefs, foodservice entrepreneurs, culinary arts educators, as well as culinary students and culinary scientists. Many commodities and food products (for example: Parma Ham, Stilton Cheese, Tabasco Sauce) are marketed today by highlighting their historical pedigree and culinary heritage. Along with the current trend for serving heirloom varieties of fruit and vegetables, and meat from rare breed animals, it is proposed that a competitive advantage is gained from a wider understanding of culinary history. This paper offers a window into the past concerning the history of Irish Corned Beef.

\section{CORNED BEEF AND CABBAGE: THE ULTIMATE IRISH DISH?}

Corned beef and cabbage is consumed in America in large quantities each Saint Patrick's Day (1 $17^{\text {th }}$ March). It is considered by most Americans to be the ultimate Irish dish, so much so that Allen (2010) notes 'I can't believe how many times I've had to emphasize that we don't just live on corned beef, potatoes and cabbage in Ireland.' However, corned beef and cabbage is seldom eaten in modern day Ireland. It is widely reported that Irish immigrants replaced their beloved bacon and cabbage with corned beef and cabbage when they arrived in America, drawing on the corned beef supplied by their neighbouring Jewish butchers, but not all commentators believe this simplistic explanation (Andrews, 2010). This paper traces the origins and history of corned beef in Irish cuisine and chart how this dish came to represent Irish cuisine in America.

The name corned beef originates in seventeenth century England, derived from corns - or small crystals - of salt used to salt or cure the meat. The paper discusses the phenomenon that although corned beef was not widely eaten in Ireland, it was widely exported, becoming one of Ireland's leading food exports during the $18^{\text {th }}$ century, mostly from the city of Cork. Irish corned beef provisioned the British navy fleets for over two centuries and Irish corned beef was also shipped to both British and French colonies. There is evidence of a strong trade in Irish corned beef as a staple for African slaves in the French West Indies and in other French colonies. Irish corned beef also became a staple in Pacific islands visited by the British navy, where it is called 'keg'. These Pacific Islanders later corned their own beef, but sailors labelled it 'salt junk.' 


\section{CANNED CORNED BEEF AND WAR}

Kurlansky (2002:125) notes that despite giving corned beef its name, the English did more harm to its good name than the Pacific Islanders, by canning it in South America. He notes that the Irish 'continued to make it well, and it has remained a festive dish there, [along] with cabbage for Christmas, Easter, and St. Patrick's Day, the three leading holidays.' The entry on corned beef in Larousse Gastronomique actually states 'cured beef, of American origin, which can be sold in cans.' NicolasFrançois Appert (1750-1841) took an important step towards the establishment of the modern canning industry when he discovered a method of safely preserving fruits, meats, and vegetables in glass bottles (Laudan, 2006:25). The development of the canning industry aided the increased importation of foreign food to Europe (Péhaut, 1999:463). During the twentieth century, the range of canned goods introduced by Heinz, Crosse \& Blackwell, and others expanded enormously (Burnett, 1994:261).

Canned food had been viewed with suspicion at the beginning of the twentieth century due to poisoning scares, but soldiers' experiences during the war helped to popularise tinned food, particularly canned peas and corned beef (Spencer, 2004:305). One of the themes running through both culinary history and the history of science and technology is the affect war has had on accelerating change and innovation. Mintz (1996:25) suggests that war is probably the most powerful instrument of dietary change. Davidson (2006) points out that much of modern canned corned beef came from the river port of Fray Bentos in Uruguay where Justus von Liebig had set up a processing plant in 1866 to produce meat extract that was later known as 'Oxo'. In 1924, the Fray Bentos firm passed into British hands and by the height of World War Two, in 1943, over 16 million cans were exported from this town that called itself 'the kitchen of the world.' It was the Cold War, and the space race that sparked the Pillsbury Corporation and NASA to develop HACCP.

In more recent times, tinned corned beef, or bully beef, has been imported from former European colonies to Ireland, most of which was eaten in sandwiches or salads. Cattle remain important to the economic welfare of Ireland. Over 460,000 tonnes of beef (excluding offal) were exported from Ireland in 2009, more than half of that amount going to the UK market, with France, Italy and the Netherlands as the 
next largest importers of Irish beef (Bord Bia, 2009). However, it is the freshly salted joints of Irish beef - principally brisket or tail end (silverside or topside) - that is the main focus of this paper.

\section{EARLY BEGININGS}

Cattle have been central to the Irish way of life for centuries, and have fed on the rich green grass that grows so abundantly in Ireland's damp, temperate climate. Scientists have radio carbon-dated a cow bone found in an archaeological dig in County Kerry to 4,500BC. This evidence indicates the Irish as early adapters to cow's milk consumption, considering that the estimated dates given for humans first consumption of cow's milk in the Near East is 5,000-7,000BC, when they developed the enzyme needed to digest it (Murphy, 2010). At this early stage cattle were also used for traction in ploughing fields and transport, which explains why they were killed for meat mostly when they were too old to work.

\section{PLACENAMES}

The Irish obsession with cattle is evident in Irish place names. 'Bó' and ' $a r b h$ ' are the words in the Irish language for cow and bull respectively. The word 'bóthar' is Irish for road and a road was defined in width by the length and breadth of a cow. The word buachail which means boy is derived from bua (cow) and chaill (attendant), literally meaning cowboy or herdsman. Bovine Irish place names include Ardboe, Drumbo, Lough Bo, Drumshambo, Inishbofin, Clontarf and also the river Boyne (from Bóinne, Boann, or Bovinda - the goddess of the white cow), site of the famous Battle of the Boyne (1690) where the protestant co-monarch, William of Orange, was victorious over the Roman Catholic King James II. The Irish language name for Westport in County Mayo is Cathair na Mart - literally 'the city of the beef.'

\section{CATTLE RAIDS}

Cattle were a measure of wealth in Gaelic Ireland. This led to many famous cattle raids in Irish mythology, but also, notes Sexton (1998:27), militated against the consumption of beef during the early medieval period (AD500-1200). Cattle raids, according to Mahon (1998:3) were 'less a method of warfare than a sortie into another tribe's territory in which a young man might test his manhood.' Mahon points out that 
they were also part of the ceremonial inauguration of a prince or chieftain and are mentioned no less than 402 times in the Annals of Ulster. The most famous Irish cattle raid is Táin Bó Cuailnge (The Cattle Raid of Cooley) where Queen Meadhbh of Connacht attacked the men of Ulster in search of a prized Brown Bull of Cooley, so that her wealth would be more than that of her husband. This legendary epic is a part of Lebor na hUidre, the book of the Dun Cow, the oldest extant Irish Manuscript, dating from the $11^{\text {th }}$ century. Legend has it that the vellum in this book came from the hide of St Ciaran of Clonmacnoise's pet cow, hence the name. Also, cattle were used in payment or in barter and are mentioned as such in the seventh and eighth century Brehon Laws, where beef eating is associated mainly with the aristocratic classes (Sexton, 1998:26).

\section{EARLY EVIDENCE OF SALTING MEAT}

Kelly (2000:336, 341) points out that salted beef (bósall) is rarely mentioned in ancient texts. This is not surprising since salting an entire bullock would have required a large amount of salt. He also notes that there is no mention of salt mines or salt pans in pre-Norman texts and suggests that salt was produced from 'sea ash', the result of burning seaweed. The Crith Gablach refers to the use of sea ash for salting joints of meat, and the twelfth century poem Aislinge Meic Con Glinne provides evidence that beef was salted as well as bacon (Jackson, 1990):

Wheatlet, son of Milklet,

Son of juicy Bacon,

Is mine own name.

Honeyed Butter-roll

Is the man's name

That bears my bag.

Haunch of Mutton

Is my dog's name,

Of lovely leaps.

Lard, my wife,

Sweetly smiles

Across the kale-top.

Cheese-curds, my daughter,

Goes round the spit,

Fair is her fame.

Corned Beef, my son,

Whose mantle shines

Over a big tail. 
Mahon (1998:7-8) notes that beef was salted and buried in peat bog holes, a practice also common for the preservation of butter. She also notes that corned beef was a festive dish.

Gaelic reverence for cattle would explain why so little beef was eaten in the Irish diet, which centred on white meats (milk, butter and dairy produce) which did not require the death of the animal. Lucas (1960) notes that the majority of herds were cows, suggesting that bull calves were killed at birth. Sexton (1998:28) therefore proposes that there must have been a high consumption of veal throughout the calving season among the Gaelic farmers with substantial herds. Noting evidence from Irish legal texts, she also suggests that some herds of bullocks must have been kept for the aristocratic tables. Ireland is a lush country where grass grows nearly all year round and is ideal for cattle production. Andrews (2010) cites a Tipperary farmer who suggested his field of grass was so fertile 'it would fatten a bicycle!' The native Irish diet of cereal and milk based products augmented with pig meat survived relatively unchanged from prehistoric times to the introduction of the potato (Mac Con Iomaire and Gallagher, 2009). Fynes Moryson, the English travel writer, for example, writing in the early seventeenth century, states:

'They feede most on Whitemeates, and esteeme for a great daintie sower curds, vulgarly called by them Bonaclabbe. And for this cause they watchfully keepe their Cowes, and fight for them as for religion and life; and when they are almost starved, yet they will not kill a Cow, except it bee old, and yield no Milke' (Moryson 1908:vol. 4, 200-201).

Kurlansky (2002:124) refers to the trade in salt between Ireland and France from the middle ages, which would explain how the growth of large scale corned beef and bacon industries became possible. The Irish bacon industry has been discussed in a previous research paper (Mac Con Iomaire, 2003).

\section{THE CATTLE ACTS AND EMERGENCE OF CORNED BEEF INDUSTRY}

In early modern times, significant numbers of live cattle were exported to England. The Duke of Ormond's papers in the Bodleian Library (MS. Carte 68) report that between $24^{\text {th }}$ June 1663 and $24^{\text {th }}$ June 1664 , some 76,754 oxen were exported from Ireland. There was also a growing provisions trade in salt beef to the West Indies from 
the late 1650 s with the growth of the tropical sugar economies. Intense lobbying by (Northern) English cattle breeders led to the enactment by Parliament of The Cattle Acts of 1663 and 1667 prohibiting the export of cattle and cattle products to England. The first Cattle Acts placed a prohibitive duty on cattle exports to England between July and December. The 1667 Act led to an outright exclusion of exporting live animals to England from Ireland, which drastically lowered the price of beef available for sale and export as salt or 'corned' beef (Cullen 1972:13-18). Mandelblatt (2007:26) notes that this change in prices was of great benefit to the incipient Irish provisions trade. Salt beef was central to this provisions trade, indeed Truxes (1988:26-7) points out that between 1660 and 1688 Irish salted beef was the most important commodity traded from the British Isles. No other products carried from the English ports or from London matched the export volume of Irish corned beef.

Salt obviously played a major role in the production of corned beef and Ireland had a major advantage over both England and France because it enjoyed a much lower rate of salt tax, nearly one tenth that of England. Ireland only imported the best dry high quality white salt from Portugal, Spain or the South West of France. The grade of salt was as important as the cut of beef. Madlebaltt (2009:27) writes of an Irish resident of Nantes, M. Carmichael, who attempted to produce salt-beef for the French colonies. He used the inferior local sel de Guérande, because he was unable to procure Portuguese salt. He had his beef rejected after the long transatlantic crossing having been declared spoiled.

Salted provisions dominated Irish trans-Atlantic trade right up to the American Revolution (Cullen 1972:103; Truxes 1988:147). Cork city developed a highly skilled and efficient provisions industry utilizing its envied skills in curing, packing and scrutiny of product that ensured consistency and high quality of product when it reached the West Indies. There were salt beef industries based in other port cities such as Dublin, Belfast and to a lesser extent Waterford but by 1668 Cork's annual shipment of salt beef (16,960 barrels) represented half of Ireland's entire colonial beef exports (Mandelblatt 2007:27). Cork beef also reached higher prices than that of the other Irish port cities, and remained the leading source of beef entering New York and Philadelphia, despite growing influence of Belfast merchants in trading with mainland America (Truxes 1988:154). 


\section{THREE STAGES IN TRANSATLANTIC TRADE}

Truxes (1988:24) identifies three stages in Ireland's transatlantic trade between 1660 and 1731. The first phase 1660-88 was a time of massive colonial expansion in sugar monoculture in the West Indies. This industry was driven by a huge increase in slave trade from West Africa. Louis XIV's 1685 Code Noir mandated the food requirements of slaves working on French colonial sugar plantations. This edict decreed that each slave should be provisioned with 'two pounds of salt meat' (deux livres de boeuf sale), but there is debate as to how strictly it was enforced (Mandelblatt 2007:28). Mintz $(1986,1996)$ provides the seminal work on the political and sociological affects of the European love affair with sugar and sweetened beverages such as tea, coffee and chocolate. De Saint-Pierre (1773) cited in (Mintz 1986) observes:

'I do not know if coffee and sugar are essential to the happiness of Europe, but I know well that these two products have accounted for the unhappiness of two great regions of the world: America has been depopulated so as to have land on which to plant them; Africa has been depopulated so as to have the people to cultivate them'.

The main consumers of Irish salt beef in the British West Indies were white planters and settlers with the slaves there provisioned on salt fish from Newfoundland. Ships bringing salt beef from Ireland to the Caribbean would then bring rum from the West Indies to Virginia or New York and return to Ireland laden with flax seed for the Irish linen industry.

The second phase identified (1688-1714) was a time of major turmoil in Ireland and of military campaigns in Europe. The battle between James II and William III caused widespread destruction and confusion in the country. The Anglo-French war, 1689-97 brought about severe restrictions on overseas trade. Special licences were issued for West Indies export but French privateers played havoc with this trade up to the mid 1690s. A major outbreak of distemper in 1688 depleted Irish livestock herds and it took nearly eight years to sufficiently rebuild herds to re-enter the West Indian market. Irish salt beef, however, regained its pre-war level within two years. The final phase according to Truxes was from 1714-31. The period post the Treaty of Utrecht saw a surge in trans-Atlantic commerce but it was short lived as Ireland fell into its 
most serious economic depression of the eighteenth century. Nevertheless transAtlantic trade increased by more than $40 \%$ on average in the four years ending 1731 over the average of the four years ending 1714 (Truxes 1988:24).

\section{LAWS CONCERNING SALT BEEF TRADE}

So important was the trade in cheap Irish salt beef that both the English and French Parliaments enacted laws specifically around it. The French wrote a decree into law allowing its ships bound for the colonies to load beef in Irish ports, and also to allow Irish beef be landed, stored and re-shipped from the ports of La Rochelle, Nantes and Bordeaux without incurring taxes. Anglo-Irish landlords saw exports to France, despite the fact that England and France were at war, as a means of profiting from the Cattle Acts (Mandelblatt 2007:26). English expansion in the colonies also demanded Irish beef. During the 1760s and 1770s, $65-75 \%$ of all Irish beef was purchased by the English and French colonies combined (Cullen 1972:53-55). During the 18th century, wars played a significant role in the growth of exports of Irish beef. These wars were mainly fought at sea and navies had a high demand for Irish salted beef for two reasons, firstly its longevity at sea and secondly its competitive price.

\section{DIFFERENT GRADES OF SALT BEEF AND THEIR MARKETS}

The slaughter of cattle in August marked the beginning of the salt-beef season which ended generally in October (Mandelblatt 2007:27). The three basic grades of salt-beef were determined by the weight of the animal. 'Small beef' was the lowest grade and came from underweight animals usually slaughtered first. Next came 'cargo beef' or common mess beef and the top grade 'best mess beef' was produced from the heaviest cattle and generally slaughtered towards the end of the season. 'The beef was cut into eight pound pieces, graded, salted and packed into casks, the lower grades receiving more of the unpopular cuts such as necks and shanks. The casks were left stand for four or five days and then sealed by a cooper' (Mandelblatt 2007:27; Truxes 1988:151-2).

Lord Chief Baron Edward Willes (cited in Sexton, 1998:30) described these grades in one of his letters (c.1757-1762) to the Earl of Warrick, 
'I had the curiosity to enquire how they dispose of all parts of the ox slaughtered for exportation, and was informed, they had two methods of doing it. If it was for merchants service, the whole beef, neck as well as other coarse pieces were barrel'd up together, but if it for the English Navy, the necks and coarser pieces were not put into the barrel. They have a third sort which they call French beef, that is old cows and beeves that but half fat, which in time of peace they sell to the French. This sort of beef turns black and flabby, and almost to a jelly (no wonder sailors fed with this meat can't face our honest English Tars, who have so much better and more substantial food in their bellies).'

The period of disruption in Irish trans-Atlantic trade caused by the Williamite wars (1689-1691) created the opening for the North American states of Pennsylvania, New York, Virginia and Maryland to provision the Caribbean with salted beef and thus broke the practical monopoly in salted beef enjoyed by Ireland since the middle of the $17^{\text {th }}$ century (Truxes 1988:26-7). By 1800, England had become the main market for salted beef and pork products. This was in some way due to the provisioning of the Royal Navy but also the West Indian market was since 1780s procuring more of its provisions from North America (Cullen 1972:103). The decline continued and by 1815 exports of beef were a quarter of their 1770 peak. By the 1840 s pork and beef exports outside the British Isles were less than three percent of their 1780 levels. From the mid nineteenth century, one of Ireland's leading exports was its people (Ó Gráda, 2000).

\section{IMMIGRATION}

The first great wave of Irish immigration to America occurred in the 1600s during the new country's colonization, with the arrival of 100,000 predominantly young Catholic men. Moloney (2002:6) points out that there was no word in the Irish language for willingly departing the homeland, and that up to the early twentieth century the only term for leaving was deorai - exile. A second wave of immigrants known as the 'Scotch-Irish' settled from Pennsylvania to Georgia between 1710 and the early 1900s. They were descendants of protestant farmers from England and the lowlands of Scotland who had only been in Ireland for a few generations. Many in this wave moved to the colonies following the destruction of the linen market due to the industrial revolution and the importation of cheap cotton goods from America. The largest wave of immigration to America was in the years of and shortly after the Great 
Famine (1845-1849) when over a million Irish left for America, ten thousands of whom died on board the 'coffin ships' that transported them.

Moloney (2002:14) notes that this wave of Irish immigrants was the first ethnic immigrant group in the United States 'to carve their future largely from the urban industrial landscape.' These immigrants arrived in America to witness large-scale anti-Irish bigotry, but within a few generations they managed to carve out success at all levels of American politics. Businessmen and fraternal Irish-American organisations such as the Ancient Order of Hibernians helped fledgling politicos rise within the wing of the Democratic Party in places such as Tammany Hall. The first St. Patrick's Day Parade in New York City was held by Irish soldiers in the British Army in 1762 , but by the mid nineteenth century it became an event that was celebrated by an even more diverse crowd. Perhaps the proximity to St. Patrick's Day influenced President Lincoln's consumption of corned beef, cabbage and parsley potatoes at his inauguration dinner ( $4^{\text {th }}$ March 1861).

\section{'IF IT WASN'T FOR THE IRISH AND THE JEWS'}

There is evidence in humorous songs from the early twentieth century linking the Irish with other ethnic groups in America. The Irish come together with the Jews in many songs, such as the 1910 'It's tough when Izzy Rosenstein Loves Genevieve Malone', the 1911 'My Yiddish Colleen', and the 1912 song by Jerome and Schwartz called 'If it Wasn't for the Irish and the Jews:'

'Talk about a combination, hear my word and make a note

On St. Patrick's Day, Rosinsky pins a shamrock on his coat

There's a sympathetic feeling between the Bloom's and MacAdoos,

Why Tammany would surely fall

There'd really be no Hall at all

If it wasn't for the Irish and the Jews' (Maloney 2002:37).

Perhaps this inter-ethnic cross cooperation might explain why the Irish purchased corned beef from Jewish butchers in American cities. The most likely reason for the popularity of corned beef over bacon is the fact that corned beef, a luxury product at home, was available cheaply in America. Andrews (2010) suggests that bacon would have been equally as available from German butchers in American cities as corned 
beef was from Jewish butchers. The traditional festive link between corned beef and St Patrick's Day would also help to embed it as an Irish dish in the American psyche.

\section{CORNED BEEF IN MODERN IRELAND}

There are a number of terms (salt beef, pickled beef, hung beef, Pocoke beef) used to describe corned beef. There is also a variation of corned beef in which spices are added to the curing process to produce spiced beef, which was and still is particularly popular around the Christmas period. Some evidence is available from manuscripts in the National Library of Ireland. The O'Hara of Annaghmore Papers (MS 36,375/1/2/3), dated 1817, has a reference to Christmas Beef which is probably both salted and spiced. Both corned beef and spiced beef are ideal twin purpose meats that can be eaten hot with dinner or served cold as an impromptu dish when guests visit during the festive period, or for picnics. In the Headfort Papers (MS 25,370) dated 1953, both salt beef and corned beef are mentioned for a "picnic lunch going to the Navan Show for 8...sandwiches, lamb, corn beef, mustard, cold egg, whole tomato, lettuce, fruit cheese, biscuits, coffee' (Cashman, 2009:54).

There seems to be regional and also socio-economic variations concerning the consumption of corned beef. Daniel Corkery notes in his work The Hidden Ireland that it was commonplace in large aristocratic households, during the eighteenth century, to salt their own beef in large stone troughs after slaughter for later consumption. He notes that the Martin family would kill a bullock once a month (cited in Cowan and Sexton, 1997:29). Cullen (1981) points out that the bulk of the beef consumed by the population at this time was salted. Fresh beef was a rare and luxurious treat for all classes. Indeed, on the $27^{\text {th }}$ December 1829, Amhlaoibh Ó Súilleabháin notes in his diary that he feasted on slices of corned beef with white cabbage, spit roasted goose with bread stuffing, leg of mutton with turnips, bacon and chickens, and a roast snipe washed down with some hot port and whiskey (de Bhaldraithe 1970:61). On the $19^{\text {th }}$ October, the diarist ate 'mairtfheoil méithe agus caoirfheoil cumhra' (succulent beef and fragrant mutton) with the parish priest in the house of Michael Hickey. He also noted that on the $15^{\text {th }}$ March 1831, he hung five joints of beef, six ox tongues and half a large pig. Was he preparing them for St Patrick's Day! 


\section{BUTCHERS' MEMORIES}

The butchery of larger animals has historically been more common in cities where there is a large population to consume it (Tannahill, 1975:64). Dave Lang, development officer for the Associated Craft Butchers of Ireland, suggests that some parts of the country such as Dublin and Cork consumed more corned beef than other areas, particularly the northern counties, which have little or no knowledge of it. He recalls forty years ago, as an apprentice butcher in Buckley's in Dublin's Moore Street, they would corn 56 tail ends a week. Meat was cut differently then. The tail end was cut straight across and included the topside and the silverside, which are now individually seam butchered (telephone correspondence 27 April 2010).

Of all Irish cities, corned beef has had a long and distinctive regional association with Cork City. Paul Murphy, a fourth generation butcher at P. Coughlan Family Butchers in Cork's English Market sells over 300lbs of boneless corned beef, silverside and topside each week. He also sells corned brisket on and off the bone. He had stopped selling brisket corned beef on the bone with about four inches of fat on it, but started selling it again in recent years, as 'all the old people all ate it.' He remembers his grandfather slicing and eating this fat on bread after a few drinks and notes that he lived till he was 98 years old, 'no talk of cholesterol tablets!' Brisket is a cheaper cut than the tail end and also needs more cooking. Murphy asks new corned beef customers 'Do you like it lean, lean, lean, or do you like it fat?' If they like it lean, he sells them silverside, if fat he gives them the brisket that is boned and rolled 'like a Swiss roll.' Murphy notes that although he sells small amounts of spiced beef weekly, that at Christmas he would sell 2000lbs of spiced beef over a ten day period. He suggests that changing eating patterns have influenced the sale of beef, noting that chickens used to be for special meals and were only sold whole, but are now widely consumed and sold pre-portioned (telephone correspondence 27 April 2010). Corned beef from P. Coughlan's Family Butchers is a speciality dish in Kay Harte's 'Farmgate Café' (upstairs in the English Market), served with potatoes, cabbage and parsley sauce. 


\section{CONSUMERS' MEMORIES}

Margaret Byrne, who grew up in Dublin in the 1930s and 1940s recalls eating both corned beef and bacon regularly with cabbage and potatoes but suggests that the consumption of corned beef began to decline when people started buying their meat in supermarkets rather than from their local butchers. She noted that it was mostly silverside that was eaten and that she was often disappointed by how much the joint would shrink during the cooking process (personal correspondence 21 April 2010). Fergal Quinn, who opened the Superquinn chain of supermarkets with a store in Dundalk and in Finglas in 1960, pointed out that corned beef was a big seller when he first opened but lost market share as the years passed (personal correspondence 26 April 2010). Tony Byrne, a craft butcher in Rathgar, Dublin, noted that corned beef had been a 'once a week' dinner among many of his customers, but that although he still sold corned beef, bacon is far more popular nowadays. He attributes this to the fact that bacon is cheaper. Liam Mac Con Iomaire, who grew up in West Galway in the 1930s and 1940s has no memory of eating corned beef, noting that bacon and either lamb or mutton were the main meats, along with poultry and fish that they consumed. Their cattle were sold at market rather than slaughtered at home. It was not until he came to Dublin and married that he began to eat corned beef regularly (personal correspondence 21 April 2010).

\section{CORNING THE BEEF}

Eliza Acton, in her The Peoples Cookery Book (34 $4^{\text {th }}$ Edition c.1902) has a number of methods for salting and pickling beef in various ways including 'Hamburgh Pickle, Hung Beef, Collared Beef, and Spiced Beef'. What they all have in common is a combination of salt, saltpetre, sugar and various spices. McGee (1988:103) notes that salt has been used for thousands of years to inhibit microbial growth, which was especially important in the years before refrigeration. He reiterates the English origin of the term corned beef coming from 'corns' or whole grains of salt and points out that, beginning in the $16^{\text {th }}$ and $17^{\text {th }}$ centuries, nitrites began to be added to the curing process in the form of a nitrate salt, saltpetre. Paul Murphy, previously mentioned, notes that they stopped using saltpetre in his family's business years ago, but recalls buying it in the chemist shop as a boy for the making of corned beef. He recalls that when two older boys went to buy the saltpetre one day, they were detained by the 
police on suspicion of making explosives! The saltpetre changed the pigment of the meat, so nowadays Murphy adds some colouring to his brine made from coarse salt because 'psychologically people want to see the bloom on the corned beef.' He points out the saltpetre hardened the meat, and that he advises his customers today that there is no need to soak his corned beef as it is not half as salty as it was in the past, when refrigeration was not as widespread. Today's corned beef is predominantly made using brine which is injected into the beef using a pickling gun or pump.

\section{SUMMARY AND CONCLUSIONS}

From ancient times in Ireland, cattle were highly prized as a sign of wealth, which militated against the consumption of beef during the early medieval period (AD5001200). Evidence exists in legal and other texts, however, that both fresh beef and salted beef were eaten in Ireland, particularly among the aristocracy and at festive occasions. The Elizabethan period witnessed the end of the traditional Gaelic way of life in most of Ireland and cattle became an economic commodity that was exported to the English markets. The emergence of British sugar-eating and tea-drinking took place against a background of overseas expansion and colonial conquest (Mintz, 1996:19). The growth of sugar plantations in the West Indies and the introduction of the Cattle Acts $(1663,1667)$ led to the setting up of commercial corned beef industries in Irish port cities, most significantly in the city of Cork, which prospered for nearly two centuries. Different grades of Irish corned beef provisioned the British Navy for centuries and were also shipped by the French to their colonies. Competition from mainland America in the late eighteenth century was one factor in the demise of the trans-Atlantic trade in Irish salt beef.

Irish salt beef was introduced by the British Navy to the Pacific Islands where it became known as 'keg' and began to be poorly copied and labelled 'salt junk' by the sailors. The setting up of beef processing plants in South America in the late nineteenth century which led to the widespread introduction to England of canned 'bully beef' sold as corned beef damaged the name of the salted joints of beef that Cork and Ireland had been previously famous for. This canned corned beef was widely distributed as pack rations during World War Two, which led to its popularity and widespread assimilation into the food habits of various nations. The influence of 
war both as an instrument of dietary change, and on accelerating innovation in food technology has been discussed. The entry for corned beef in Larousse Gastronomique only mentions the canned American version and has no reference to the earlier Irish salt beef tradition.

This paper identifies that corned beef has always been an aristocratic food in Ireland and particularly a festive dish eaten at Christmas, Easter and St. Patrick's Day. It suggests that the most probable reason for the popularity of corned beef among the Irish Americans was not the lack of availability of bacon, as sometimes argued, but that corned beef was widely available at a reasonable price. Irish immigrants aspired to better themselves in America and part of this betterment was the consumption of foodstuff they might not have been able to afford at home. This along with the fact that corned beef has long been associated with St. Patrick's Day has led to the widespread, but erroneous view among many Americans that Irish cuisine consists almost exclusively of corned beef, cabbage and potatoes.

This paper proposes that a better knowledge of culinary history enriches all culinary stakeholders including consumers, food technologists, research chefs, foodservice entrepreneurs, culinary arts educators, as well as culinary students and culinary scientists. If, as the aphorism suggests, we are what we eat, then what we eat and what our forefathers ate also shapes and has shaped the world we inhabit. This generation's food technology and consumption practices will be the subject of future generations' culinary history.

\section{BIBLIOGRAPHY}

Albala, K. (2007). Beans: A History. Oxford: Berg.

Allen, D. (2010). Foreword. In C. Andrews, The Country Cooking of Ireland, San Francisco: Chronicle Books.

Andrews, C. (2010). The Country Cooking of Ireland. San Francisco: Chronicle Books.

Barlösius, E. (1988). Eßgenu $\beta$ als eigenlogisches soziales Gestaltungsprinzip. Zur Soziologie des Essens und Trinkens, dargestellt am Beispiel der grande cuisine Frankreichs (Unpublished Ph.D. Thesis), Universität Hannover.

Bord Bia (2009). Performance and Prospects Food and Horticulture Exports 2009/2010. Dublin: Bord Bia - Irish Food Board (available www.bordbia.ie). 
Burnett, J. (1994). Plenty \& Want: A Social History of Food in England from 1815 to the Present Day (3rd Edition). London: Routledge.

Cashman, D. (2009). An Exploratory Study of Irish Cookbooks. (Unpublished M.Sc. Thesis). Faculty of Tourism and Food: Dublin Institute of Technology.

Coe, S. D. (2003). The true history of chocolate. London: Thames \& Hudson.

Cowan, C. and Sexton R. (1997). Ireland's Traditional Foods. Dublin: Teagasc.

Cullen, L. M. (1972). An Economic History of Ireland since 1660. London: Batsford.

Cullen, L.M. (1981). The Emergence of Modern Ireland 1600-1900. London: Batsford Academic.

Davidson, A. (2006). The Oxford Companion to Food ( $2^{\text {nd }}$ Edition). New York: Oxford University Press.

De Bhaldraithe, T. (1970). Cín Lae Amhlaoibh. Baile Átha Cliath: An Clóchomhar.

de Saint-Pierre, J. H. B. (1773). Voyage to Isle de France, Isle de Bourbon, The Cape of Good Hope... With New Observations on Nature and Mankind by an Officer of the King. (Vol. 1). London: W. Griffin.

Jackson, K. H., (ed.) (1990). Aislinge Meic Con Glinne. Dublin: Dublin Institute for Advanced Studies.

Kelly, F. (2000). Early Irish Farming. Dublin: Dublin Institute for Advanced Studies.

Kurlansky, M. (1997). Cod: a biography of the fish that changed the world. New York: Walker \& Co.

Kurlansky, M. (2002). Salt: a world history. London: Jonathan Cape.

Kurlansky, M. (2007). The big oyster: a molluscular history of New York. London: Vintage.

Laudan, R. (2006). Nicolas-François Appert. In A. Arndt (ed.), Culinary Biographies, (pp. 25-27). Houston, Texas: Yes Press.

Lucas, A. T. (1960). Irish food Before the Potato. Gwerin, III (2), 8-43.

Mac Con Iomaire, M. (2003). The Pig in Irish Cuisine and Culture. In H. Walker (ed.), The Fat of the Land: Proceedings of the Oxford Symposium on Food and Cookery 2002, (pp. 207-215). Bristol: Footwork.

Mac Con Iomaire, M. (2009). The Emergence, Development, and Influence of French Haute Cuisine on Public Dining in Dublin Restaurants 1900-2000: An Oral History (Doctoral Thesis). School of Culinary Arts \& Food Technology. Dublin, Dublin Institute of Technology: http://arrow.dit.ie/tourdoc/12/.

Mac Con Iomaire, M. and Gallagher, P. (2009). The Potato in Irish Cuisine and Culture. Journal of Culinary Science \& Technology. 7(2-3), 152-167.

Mahon, B. (1998). Land of Milk and Honey. Cork: Mercier Press.

Mandelblatt, B. (2007). A Transatlantic Commodity: Irish Salt Beef in the French Atlantic World. History Workshop Journal, 63, 18-47.

McGee, H. (1987). On Food and Cooking. London: Unwin Hyman.

McGee, H. (1990). The Curious Cook: more kitchen science and lore. New York: Macmillan USA.

McGee, H. (2004). McGee on Food and Cooking: an encyclopedia of kitchen science, history and culture. London: Hodder \& Stoughton.

Messer, E., Haber, B., Toomra, J., and Wheaton, B. K. (2000). Culinary History. In K.F. Kiple and K. C. Ornelas (eds.) The Cambridge World History of Food, (pp. 1367-1380). Cambridge: Cambridge University Press.

Mintz, S. W. (1986). Sweetness and Power: The Place of Sugar in Modern History. New York: Penguin.

Mintz, S. W. (1996). Tasting Food, Tasting Freedom: Excursions into Eating, Culture, and the Past. Boston: Beacon Press. 
Moloney, M. (2002). Far from the Shamrock Shore. Cork: The Collins Press.

Montgomery, D.R. (2003). King of Fish: The Thousand-Year Run of Salmon. Boulder, Colorado: Westview Press.

Moryson, F. (1908). An Itinerary. Glasgow: MacLehose.

Murphy, K. (2010). Land of Milk not Money. The Irish Times (13 March) pp.12-13.

Ó Gráda, C. (2000). Black '47 and beyond: The Great Irish Famine in history, economy and memory. Princeton, NJ: Princeton University Press.

O'Gorman, K. D. (2010). The Origins of Hospitality and Tourism. Oxford: Goodfellow Publishers Limited.

Péhaut, Y. (1999). The Invasion of Foreign Foods. In J.-L. Flandrin and M. Montanari (eds.), Food: A Culinary History from Antiquity to the Present, (pp. 457-470). New York: Columbia University Press.

Reader, J. (2008). Propitions Esculent: The Potato in World History. London: William Heinemann.

Sexton, R. (1998). A Little History of Irish Food. Dublin: Gill \& Macmillan.

Spang, R. L. (1993). A Confusion of Appetites: The Emergence of Paris Restaurant Culture, 1740-1848. (Unpublished PhD Dissertation), Cornell University.

Spencer, C. (2004). British Food: An Extraordinary Thousand Years of History. London: Grub Street.

Tannahill, R. (1975). Food in History. St Albans, Herts.: Paladin.

Trubek, A. (1995). The empire of the senses: French haute cuisine and the rise of the modern culinary profession, 1870-1910 (Unpublished $\mathrm{PhD}$ Thesis). Department of Anthropology, University of Pennsylvania: 276.

Truxes, T. M. (1988). Irish-American Trade 1660-1783. Cambridge: Cambridge University Press.

Turner, J. (2005). Spice: The History of Temptation. London: Harper Perennial.

Received: 24/09/2010

Revised: 29/09/2010

Secondary Revision 7/1/2011 